\title{
PENGARUH MODEL PEMBELAJARAN KOOPERATIF TIPE TIME TOKEN TERHADAP KEMAMPUAN KOMUNIKASI DAN AKTIVITAS BELAJAR SISWA KELAS VIII SMP NEGERI 2 SINGARAJA
}

\author{
P. S.Githa, I.M.Sugiarta, I. W. P. Astawa \\ Jurusan Pendidikan Matematika Universitas Pendidikan Ganesha \\ Singaraja, Indonesia \\ e-mail: \{srimarch.githa,made.sugiarta,puja.astawa\}@undiksha.ac.id
}

\begin{abstract}
Abstrak
Penelitian ini bertujuan untuk mengetahui kemampuan komunikasi matematika dan aktivitas belajar siswa yang mengikuti model pembelajaran kooperatif tipe Time Token. Penelitian ini adalah penelitian eksperimental semu. Data yang diperoleh melalui postes dan hasil observasi dianalisis menggunakan uji MANOVA dengan taraf signifikasi 5\%. Hasil penelitian menunjukan bahwa model pembelajaran kooperatif tipe time secara bersama berpengaruh terhadap kemampuan komunikasi dan aktivitas belajar siswa $(F=22,276 ; \quad p<0,05)$; secara tersendiri berpengaruh positif terhadap kemampuan komunikasi matematika siswa $(F=34,726 ; p<0,05)$; dan aktivitas belajar siswa $(F=12,257 ; p<0,05)$.
\end{abstract}

Kata kunci: model pembelajaran kooperatif tipe Time Token, kemampuan komunikasi matematika dan aktivitas belajar

\begin{abstract}
This study is aimed for determining student's mathematical communication ability and learning activities which is given by using Time token as cooperativelearrning model. This study is a quasi experiment. The data which was obtained through post-test and observation results are analyzed by using MANOVA with $5 \%$ significance level. The results of hypothesis testing shows that : firstly, the students' mathematical communication ability and learning activities that is learned by using Time Token as cooperative model is better than the students who learn in conventional learning ( $F=22,276 ; p<0.05)$. Secondly, , the students' mathematical communication ability that is learned by using Time Token as cooperative model is better than the students who learn in conventional learning ( $F=34,726$; $p<0,05)$; and, the students' learning activities that is learned by using Time Token as cooperative model is better than the students who learn in conventional learning $(F=12.257 ; p$ $<0.05$ ).
\end{abstract}

Keywords: Cooperative Learning Model Time Token Type, Mathematical Comuniccation ability and Learning Activities.

\section{PENDAHULUAN}

Pendidikan merupakan hal yang penting dalam kehidupan, ini berarti bahwa setiap manusia khususnya masyarakat Indonesia berhak mendapatkan pendidikan dan diharapkan untuk selalu berkembang didalamnya karena ke- majuan suatu negara dapat diukur atau dapat dilihat dari kemajuan pendidikan masyarakatnya. Sasaran pendidikan yaitu manusia itu sendiri karena manusia sejak lahir sudah terlibat dalam dunia pendidikan. Manusia sejak kecil dirawat, dijaga, dan dididik oleh orang tua, keluarga, dan masyarakat menuju tingkat 
kedewasaan dan kematangan hidupnya (Suardi, 2012). Melalui pendidikan, kehidupan manusia akan menjadi terarah, sehingga manusia dapat memenuhi kebutuhannya. Oleh karena itu, peningkatan kualitas dan mutu pendidikan sangatlah diperlukan.

Menurut Suardi (2012), pendidikan dapat diartikan sebagai sarana yang menumbuh kembangkan potensi-potensi kemanusiaan untuk bermasyarakat dan menjadi manusia yang sempurna. Pendidikan yang mampu mengimbangi pesatnya perkembangan ilmu pengetahuan dan teknologi adalah pendidikan yang mampu mengembangkan secara maksimal potensi yang dimiliki oleh individu, sehingga mampu mengatasi permasalahan yang dihadapinya nanti. "IImu pengetahuan dan teknologi tidak akan berkembang tanpa adanya kotribusi dari matematika" (Suherman, 2003:15). Pendidikan merupakan suatu usaha yang dengan sengaja dirancang untuk mencapai tujuan yang telah ditetapkan, Pendidikan juga merupakan investasi dalam pengembangan sumber daya manusia dimana peningkatan kecakapan. Oleh karena itu Pendidikan bertujuan untuk meningkatkan kualitas sumber daya manusia.

Pendidikan berdasarkan lingkungannya memiliki tiga jenis yaitu, pendidikan formal, pendidikan non-formal dan pendidikan informal. Pendidikan nonformal adalah pendidikan yang didapat di luar sekolah dan terstruktur dan berjenjang seperti contohnya yaitu bimbingan belajar dan tes yang diselenggarakan oleh pemerintah seperti halnya ujian paket $C$ dan masih banyak lainnya. Pendidikan informal yaitu pendidikan yang diperoleh dari lingkungan keluarga. Pendidikan formal merupakan salah satu wahana untuk menciptakan sumber daya manusia yang berkualitas. Belajar yang dilakukan pada pendidikan formal, terjadi ketika siswa mendapatkan informasi yang disampaikan guru di kelas.

Menurut NCTM (National Council of Teacher of Mathematics, 2000) terdapat lima kemampuan penting yang perlu dikembangkan dalam pembelajaran matematika, yaitu pemecahan masalah, penalaran dan pembuktian, komunikasi, koneksi, dan representasi. Terkait dengan tujuan utama pembelajaran dan lima kemampuan penting yang perlu dikembangkan dalam pembelajaran matematika tersebut, kemampuan komunikasi matematika merupakan salah satu kemampuan yang memegang peranan penting dalam pembelajaran matematika. Komunikasi matematika merupakan kemampuan siswa untuk dapat menuangkan ide dalam menjelaskan konsep matematika yang telah dipelajari. Kemampuan siswa ini dapat dinilai melalui jawaban yang diberikan oleh siswa. Jawaban tersebut merupakan cara siswa untuk mengomunikasikan ide yang dimiliki terkait permasalahan yang diberikan, baik secara tertulis maupun lisan sehingga mereka berlatih untuk dapat menjelaskan, mengemukakan pendapat, dan mempertanggungjawabkan ide yang dimiliki.

Namun kenyataannya, sering kali ditemukan siswa mengalami kesulitan dalam mengekspresikan ide-ide matematika. Kesulitan ini dikarenakan siswa masih bingung dalam menggunakan dan menafsirkan notasi-notasi serta menangkap ide-ide dan konsep. Pernyataan ini didukung oleh Laely (2014) yang menyebutkan bahwa kemampuan komunikasi matematika siswa masih rendah. Masih banyak siswa belum mampu menghubungkan ide-ide yang telah didapatkannya sehingga mereka tidak dapat mencari penyelesaian dari permasalahan, tidak mampu menghubungkan permasalahan yang dihadapi dengan konteks kejadian yang ada dalam kehidupan nyata.

Masalah yang dihadapi oleh guru adalah bagaimana supaya siswa mau belajar, tidak hanya belajar mendengarkan penjelasan guru saja, melainkan ikut terlibat aktif dalam proses pembelajaran. Pada prinsipnya belajar adalah berbuat untuk mengubah tingkah laku yang disebut aktivitas. Aktivitas adalah kegiatan yang bersifat fisik maupun mental, yaitu berbuat dan berfikir sebagai suatu rangkaian yang tidak dapat dipisahkan (Sardiman,2001 :98). Tidak ada belajar jika tidak ada aktivitas. 
Belajar yang berhasil harus melalui berbagai macam aktivitas. Untuk menciptakan suasana siswa aktif dalam pembelajaran dibutuhkan model pembelajaran yang tepat. Selama ini proses belajar yang diterapkan adalah model konvensional. Pembelajaran terpusat pada guru, sehingga siswa lebih cenderung sebagai penerima pasif yang hanya mendengarkan penelasan guru. Siswa yang aktif terlibat dalam kegiatan pembelajaran di kelas, hanya sebagian kecil saja. Sebagaian besar siswa hanya sebagai pendengar saja atau sebagai penggangu konsentrasi belajar temannya. Bila siswa belajar hanya melalui pendengaran saja, tanpa melakukan aktivitas lain berupa keterlibatan fisik maupun mental, maka ranah yang dicapai hanya kognitifnya saja. Ranah psikomotorik dan efektifnya menjadi kurang berkembang.

Cindya (2010) menyatakan bahwa proses pembelajaran masih banyak terlihat suasana kelas yang cenderung berpusat pada guru, dimana guru hanya menggunakan metode ceramah sehingga siswa menjadi pasif. Padahal materi yang diajarkan pada saat proses pembelajaran berlangsung dapat menjadi sangat menyenangkan bagi siswa apabila guru dapat dengan kreatif menggunakan model, strategi, ataupun metode belajar dalam pembelajarannya. Tanpa disadari pembelajaran seperti ini akan menimbulkan dampak yang kurang baik bagi siswa, karena siswa tidak mempunyai kesempatan untuk mengembangkan pengetahuannya. Secara langsung dapat dikatakan siswa tidak memiliki aktivitas pada proses pembelajaran dikelas. Aktivitas belajar siswa perlu dipandang untuk diamati dalam proses pembelajaran, menyangkut tentang bagaimana keterlibatan dan partisipasi siswa pada saat proses pembelajaran berlangsung.

Masalah yang dihadapi oleh guru dalam hal ini pembelajaran matematika, dimana dalam pembelajaran matematika memiliki tujuan yaitu tuntas dalam hal berhasil menyelesaikan tujuan pembelajaran serta dapat meningkatkan aktivitas siswa dalam pembelajaran. Kita ketahui siswa memiliki karakteristik, pengalaman, kemampuan, dan cara belajar yang ber- beda satu dengan lainnya. Dalam pembelajaran konvensional cenderung didominasi oleh siswa yang memiliki kemampuan lebih di kelas, sehingga tidak meratanya perkembangan psikomotorik yang terjadi di kelas tersebut (Ratna, 2009).

Menyikapi permasalahan tersebut dan mengingat pentingnya komunikasi matematika dan aktivitas belajar dalam pembelajaran matematika siswa, guru diharapkan mengupayakan pembelajaran matematika di sekolah dirancang untuk membiasakan siswa mengkontruksi sendiri pengetahuannya dan dapat mendukung serta mengarahkan siswa untuk mengembangkan kemampuan komunikasi matematikanya. Penggunaan model pembelajaran yang sesuai dengan keadaan siswa dapat menciptakan suasana pembelajaran yang lebih kondusif serta mampu mendorong tumbuhnya rasa senang siswa terhadap suatu pelajaran. Terdapat beberapa model pembelajaran, salah satunya adalah model pembelajaran kooperatif. Pembelajaran kooperatif digunakan untuk mewujudkan kegiatan belajar mengajar yang berpusat pada siswa, terutama untuk mengatasi permasalahan yang ditemukan guru dalam mengaktifkan siswa, yang tidak dapat berkerja sama dengan orang lain, siswa yang agresif dan tidak peduli pada yang lain.

Peningkatan kemampuan komunikasi matematika serta berdampak pada peninggkatan aktivitas belajar siswa, memerlukan kreatifitas guru dalam membuat proses pembelajaran matematika menjadi lebih menarik dan menyenang-kan. Guru diharapkan dapat menerapkan modelmodel pembelajaran yang inovatif dan mampu membangun suasana belajar yang kondusif dan menyenangkan. Salah satu model pembelajaran yang dapat digunakan adalah model pembelajaran kooperatif.

Pembelajaran kooperatif adalah suatu pembelajaran yang menggunakan grup kecil dimana siswa bekerjasama belajar satu sama lain, berdiskusi dan saling berbagi ilmu pengetahuan, saling berkomunikasi, saling membantu untuk memahami materi pelajaran. Siswa secara 
berkelompok mengembangkan kecakapan hidupnya, seperti menemukan dan memecahkan masalah, pengambilan keputusan, berpikir logis, berkomunikasi efektif, dan bekerja sama.

Time token berasal dari kata time yaitu waktu dan token yang artinya tanda. Ciri khas dari model pembelajaran kooperatif tipe time token adalah adanya kartu bicara yang diberikan pada masing masing kelompok. Kartu bicara ini terdiri dari kartu menjawab, kartu bertanya dan kartu menanggapi yang mana kartu ini digunakan untuk membahas masalah yang akan diskusi serta dapat menyimpulkan hasil diskusi selama pembelajaran. Ketika salah satu kelompok menggunakan kartu menjawab untuk menyampaikan hasil diskusi kelompoknya, kelompok lain wajib menggunakan kartu bertanya dan untuk kartu menanggapi bisa digunakan oleh kelompok yang sudah menggunakan kartu menjawab maupun kelompok lain. Kegiatan ini menimbulkan interaksi antar siswa dalam menyampaikan pemikiran yang dapat membuat siswa memahami, menginterprestasi dan me-ngevaluasi ide -ide matematika secara lebih baik.

Arends (2008) menjelaskan bahwa model pembelajaran kooperatif tipe Time Token mempunyai fungsi struktur- struktur persentasi yang mengijinkan berbagi ide, solusi secara efisien. Jika kartu kelompoknya telah habis maka kelompok tidak boleh berbicara sampai semua kelompok yang lain juga meng-habiskan kartu mereka. Jadi siswa memiliki kesempatan yang sama untuk berpartisipasi didalam pembelajaran. Model pembelajaran ini menuntut siswa untuk mempersiapkan diri sebelum proses pembelajaran berlangsung. Siswa yang aktif di dalam kelas biasanya adalah siswa yang telah mempersiapkan dirinya dengan baik sebelum mengikuti pembelajaran di dalam kelas. Siswa yang memiliki aktivitas belajar yang tinggi akan dapat mengikuti pembelajaran dengan baik dan mudah menyerap pelajaran yang disampaikan ketika dalam proses pembelajaran.

Berbagai temuan penelitian menunjukan bahwa model pembelajaran kooperatif tipe Time Token membantu guru dan siswa mencapai tujuan pem- belajaran. Seperti penelitian dilakukan oleh Fitriah (2014) dan Octamela (2016), hasil yang diperoleh oleh kedua peneliti tersebut yaitu model pembelajaran kooperatif tipe time token dapat berpengaruh positif. Peneliti juga menyarankan untuk menggunakan model pembelajaran kooperatif tipe Time Token sebagai salah satu metode alternatif dalam pembelajaran matematika.

Berdasarkan pemaparan tersebut, penulis menduga pembelajaran kooperatif tipe Time token dapat meningkatkan kemampuan komunikasi matematika dan aktivitas belajar siswa. Oleh karena itu, penulis termotivasi untuk mengadakan penelitian eksperimen dengan judul penelitian "Pengaruh Model Pembelajaran Kooperatif Tipe Time Token terhadap Kemampuan Komunikasi Matematika dan Aktivitas Belajar Siswa Kelas VIII di SMP Negeri 2 Singaraja"

\section{METODE PENELITIAN}

Rancangan penelitian yang digunakan adalah penelitian eksperimen semu dengan desain (The Posttes-only Control Group Desaign). Populasi penelitian ini adalah siswa kelas VIII SMP Negeri 2 Singaraja tahun ajaran 2018/2019. Pengambilan sampel pada penelitian ini menggunakan teknik cluster random sampling, mengambil 2 kelas secara acak untuk menentukan kelas kontrol dan eksperimen, diperoleh kelas VIII.9 sebagai kelas kontrol dan kelas VIII.11 sebagai kelas eksperimen. Pada kelas eksperimen menggunakan model pembelajaran kooperatif tipe time token. Sedangkan kelas kontrol menggunakan model pembelajaran konvensional.

Instrumen yang digunakan dalam penelitian ini adalah tes esai yang digunakan untuk mengukur kemampuan komunikasi matematis siswa dan instrumen lembar observasi yang digunakan untuk menilai aktivitas belajar siswa. Sesuai hasil uji validitas dan uji reabilitas, instrumen dapat digunakan untuk mengukur kemampuan komunikasi dan aktivitas belajar siswa.

Dalam penelitian ini diajukan tiga hipotesis penelitian, untuk mengujinya digunakan uji MANOVA. Sebelum uji 
MANOVA, dilakukan uji prasyarat yaitu: uji normalitas menggunakan uji liliefors, uji homogenitas matrik varians-kovarian menggunakan uji Box's $M$. Uji kolinearitas menggunakan uji korelasi product moment dan dilanjutkan dengan melakukan uji MANOVA. Analisisnya digunakan bantuan program SPSS-PC 16.0 for windows. Semua pengujian hipotesis dilakukan pada taraf $5 \%$.

\section{HASIL DAN PEMBAHASAN}

Nilai rata-rata $(\bar{X})$ dan standar deviasi pada kelas eksperimen dan kontrol terhadap kemampuan komunikasi dan aktivitas belajar siswa, dapat dilihat pada Tabel 1.

Tabel 1. rata-rata $(\bar{X})$ dan standar deviasi pada kelas eksperimen dan kontrol terhadap kemampuan komunikasi dan aktivitas belajar siswa

\begin{tabular}{lcccc}
\hline Variabel & \multicolumn{2}{c}{ Time token } & \multicolumn{2}{c}{ Konvensional } \\
\cline { 2 - 5 } & rerata & SD & rerata & SD \\
$\begin{array}{l}\text { Kemampuan } \\
\text { komunikasi }\end{array}$ & 81,87 & 9,90 & 67,63 & 9.03 \\
$\begin{array}{l}\text { Aktivitas } \\
\text { belajar }\end{array}$ & 85,17 & 9,76 & 76,87 & 9,02 \\
\hline
\end{tabular}

Berdasarkan tabel diatas, tampak bahwa kemampuan komunikasi pada kelompok model pembelajaran kooperatif tipe time token memiliki $(\bar{X})=81,87$ dengan standar deviasi $S D=9,90$. Sedangkan pada kelompok model pembelajaran konvensional memiliki rata-rata $(\bar{X})=67,63$ dengan $\mathrm{SD}=9,03$. Selain itu tampak aktivitas belajar siswa pada kelompok model pembelajaran kooperatif tipe time token memiliki rerata $(\bar{X})=85,17$ dengan $S D=9,76$, sedangkan pada kelompok konvensional memiliki rerata $(\bar{X})=76,87$ dengan $\mathrm{SD}=9,02$. Hasil ini mengindikasikan bahwa secara deskriptif model pembelajaran kooperatif tipe time token lebih baik dari pada model pembelajaran konvensional.

Berdasarkan analisis MANOVA, diperoleh bahwa secara bersama-sama model pembelajaran kooperatif tipe time token berpengaruh positif terhadap kemampuan komunikasi matematika dan aktivitas belajar siswa dengan nilai statistik ( $F=22,276, p<0,05)$. Berdasarkan analisis Tests of Between-Subjects Effects, secara sendiri-sendiri bahwa model pembelajaran kooperatif tipe time token berpengaruh positif terhadap komunikasi matematika siswa dengan nilai statistik $(F=34,726$ $\mathrm{p}<0,05)$ dan model pembelajaran kooperatif tipe time token berpengaruh positif terhadap aktivitas belajar siswa dengan nilai statistik $(F=12,257 p<0,05)$.

\section{KESIMPULAN DAN SARAN}

Berdasarkan hasil penelitian dan pembahasan, diperoleh beberapa kesimpulan. Pertama, kemampuan komunikasi matematika dan aktivitas belajar siswa yang mengikuti model pembelajaran kooperatif tipe time token lebih baik daripada kemampuan komunikasi matematika dan aktivitas belajar siswa yang mengikuti pembelajaran konvensional. Kedua, kemampuan komunikasi matematika siswa yang mengikuti model pembelajaran kooperatif tipe time token lebih baik daripada kemampuan komunikasi matematika siswa yang mengikuti pembelajaran konvensional. Ketiga, aktivitas belajar siswa yang mengikuti model pembelajaran kooperatif tipe time token lebih baik daripada aktivitas belajar siswa yang mengikuti pembelajaran konvensional. Berdasarkan temuan-temuan di atas disimpulkan bahwa model pembelajaran kooperatif tipe time token berpengaruh posif terhadap kemampuan komunikasi dan aktivitas belajar siswa.

Berdasarkan hasil penelitian yang telah dilakukan, peneliti melalui tulisan ini menyampaikan beberapa saran sebagai berikut.

1.Kepada praktisi pendidikan matematika, khususnya guru pelajaran matematika diharapkan dalam pembelajaran di kelas untuk menerapkan model pembelajaran kooperatif tipe Time Token sebagai salah satu alternatif pembelajaran mengingat pengaruh positif yang diberikan model ini terhadap ke- 
mampuan komunikasi matematika dan aktivitas belajar siswa

2.Penelitan ini hanya sebatas mengetahui pengaruh model pembelajaran kooperatif tipe Time Token terhadap kemampuan komunikasi matematika dan aktivitas belajar siswa. Bagi peneliti lain yang tertarik disarankan agar menguji cobakan pengaruh mo-del ini pada aspek pembelajaran yang lainnya, misalnya kemampuan penalaran matematika.

\section{DAFTAR PUSTAKA}

Arends, Richard I. 2008. Learning To Teach, Yogyakarta: Pustaka Belajar.

Arikunto, S. 2006. Prosedur Penelitian Suatu Pendekatan Praktik (Edisi Revisi VI). Jakarta: PT Rineka Cipta.

Aunurrahman, 2009. Belajar dan Pembelajaran.

Pontianak:Penerbit Alfabeta.

Candiasa, I. M. 2007. Statistika Multivariat. Singaraja: Program Pasca Sarjana.

Dimyati \& Mudjiono,2010. Belajar dan Pembelajaran. Jakarta: Rineka Cipta

Fitriah, dkk. 2014. Eksperimentasi Model Pembelajaran Time Token dan Take and Give Terhadap Prestasi Belajar dan Keaktifan. E-journal Universitas Muhamadiyah Purworejo. Vol 12. No. 1

Nanang Hanafiah dan Cucu Suhan. 2009. Konsep Strategi Pembelajaran. Bandung: PT. Refika Aditama.

NCTM. 1989. Curriculum and Evaluation Standard for School Mathematics. Virginia:The NCTM Ine.
Octamela.2016."Pengaruh pembelajaran Kooperatif Tipe Time Token Terhadap Kesiapan Belajar Siswa SMP".Disertai (tidak diterbitkan).SPS UPI.

Sadirman,A. M. 2001. Interaksi dan Motivasi Belajar Mengajar. Jakarta : PT Raja Grafindo Persada.

Sudjana,N 1989. Penelitian Hasil Proses Belajar mengajar. Bandung: Sinar Baru Algensido.

Sugiyono.20013.Metode Penelitian Pendidikan (Pendekatan Kualitatif, Kuantitatif, R\&D). Bandung:Alfabeta.

Suherman, Erman dkk. 2003. Strategi Belajar Mengajar Matematika Kontemporer. Jakarta: Dirjen Dikti Depdiknas.

Ridwan, Yudhanegara, dkk. 2015. Penelitian Pendidikan Matematika Bandung: PT Refika Aditama 